\title{
СТРУКТУРА ИСПОЛЬЗОВАНИЯ ЗЕМЕЛЬ ПАРТИЗАНСКОГО МУНИЦИПАЛЬНОГО РАЙОНА И ПАРТИЗАНСКОГО ГОРОДСКОГО ОКРУГА
}

\author{
Музыченко T.К. \\ Тихоокеанский институт географии ДВО РАН, Владивосток \\ Дальневосточный федеральный университет, Владивосток \\ muzychenko.tk@gmail.com
}

Аннотация. В данной статье была рассмотрена структура землепользования в Партизанском муниципальном районе и Партизанском городском округе за сентябрь 2017 г. Было выполнено картографирование типов земель на основе спутниковых снимков Sentinel-2 за сентябрь 2017 г. посредством использования программного пакета ArcMap 10.5. Приведены площади и доли от общей площади субъектов различных типов земель, а также карта землепользования юго-восточной части Партизанского городского округа. Проанализированы закономерности в пространственном распределении различных типов земель и сопоставление площадей типов использования земель между Партизанским муниципальным районом и Партизанским городским округом. Было установлено, что с большим отрывом доминирующими типами земель в данных субъектах являются лесные угодья и редколесья. Преобладание лесных угодий характерно для менее освоенных в хозяйственном плане территорий, которые располагаются в восточной и крайней северной части Партизанского муниципального района. Они также отличаются разреженной транспортно-дорожной сетью, а земли населенных пунктов и сельскохозяйственные угодья либо расположены в виде небольших ареалов на большом отдалении друг от друга, либо отсутствуют вовсе. В освоенных в хозяйственном плане районах изучаемых субъектов ареалы лесных угодий вытесняются редколесьями и лугами. Транспортно-дорожная сеть отличается относительной развитостью. Размеры ареалов земель населенных пунктов и сельскохозяйственных угодий увеличиваются и располагаются на меньших друг от друга расстояниях. Наиболее высокой хозяйственной освоенностью отличается долина р. Партизанской, южная часть Партизанского городского округа, а также южная часть Партизанского муниципального района, примыкающая к Находкинскому городскому округу. В целом, Партизанский муниципальный район отличается большей концентрацией сельскохозяйственных угодий и более равномерной хозяйственной освоенностью, чем Партизанский городской округ. В силу орографических особенностей территории Партизанский район также захватывает больше земель с горно-тундровой и подгольцовой растительностью, а Партизанский городской округ за счет г. Партизанск имеет более солидную долю земель населенных пунктов.

Ключевые слова: геоэкология, использование земель, хозяйственное освоение, межрегиональные различия, Приморский край. 


\title{
LAND USE STRUCTURE OF PARTIZANSKY DISTRICT AND PARTIZANSKY URBAN OKRUG
}

\author{
Muzychenko T.K. \\ Pacific Geographical Institute FEB RAS, Vladivostok \\ Far Eastern Federal University, Vladivostok
}

Annotation. In the following paper September 2017 land use structure of Partizansky district and Partizansky Urban Okrug was reviewed. Patterns in spatial distribution of certain land use types were identified and interregional differences were assessed, using 1:350 000 scale land use map composed using Sentinel-2 satellite imagery and ArcMap 10.5 software package. Gross areas and its percentages of total region area were calculated for each type of land. A fragment of land use map has been presented in the paper, exhibiting the prevailing types of land use in the southeastern part of Partizansky Urban Okrug. The prevailing land type in the region is forests, taking up a little over half of the researched area, and woodlands along with shrubs. Forests are concentrated in the eastern and far northern parts of Partizansky district, which are the least economically developed parts of the researched area. They have a sparse transport network and little to no settlements and agricultural lands. Still, the regions specialize primarily in agriculture and logging, which can cause a decrease in total forest area. Woodlands and shrubs, second to forests in footprint, are prevalent in the more economically developed parts of the region, which are Partizanskaya river valley, southern part of Partizansky Urban Okrug and southern part of Partizansky district adjacent to Nakhodka Urban Okrug. These areas are characterized by forest areas being much less prevalent than the average; settlements, agricultural lands and meadows occurring much more densely and having larger than average footprints. These areas also tend to have a more developed and diverse transport network. Generally, Partizansky Urban Okrug is less evenly developed than Partizansky district, although Partizansky Urban Okrug has a significantly larger share of settlements lands. However, Partizansky district overall has a larger share of agricultural lands, meadows, woodlands with shrubs, which tend to occur in more economically developed areas.

Key words: geoecology, land use, economic development, interregional differences, Primorsky Krai.

В настоящее время в Партизанском муниципальном районе (далее - Партизанском районе) и Партизанском городском округе (далее - Партизанском ГО) идет перераспределение земельного фонда, довольно значительная часть которого используется как сельскохозяйственные угодья. Помимо этого, отмечается активная застройка под разнообразные формы собственности, производятся активные рубки леса и пр. Современная структура использования земель в этом районе отражает историю освоения территории и ее современное социально-экономическое положение. Оценка современной структуры 
земель является базисом дальнейшего развития и оценки эколого-хозяйственного баланса территории, что придает теме настоящей работы актуальность.

Целью настоящей работы является изучение современного пространственного распространения типов земель в пределах Партизанского района и Партизанского ГО.

Структура землепользования Партизанского района и Партизанского городского округа анализировалась посредством использования методов геоинформационного картографирования, картографо-статистического анализа и дешифрирования данных дистанционного зондирования, на основе чего была построена карта землепользования данных административных субъектов в масштабе 1:350 000. Картографирование было выполнено на основе спутниковых снимков Sentinel-2 за сентябрь 2017 г. с помощью программного пакета ArcMap 10.5. Научно-методическое сопровождение исследований было проведено на базе Информационно-картографического центра ТИГ ДВО РАН.

Следуя в порядке от наименее к наиболее модифицированным человеком землям, в легенде были выделены земли горно-тундровой и подгольцовой растительности, лесов, редколесий, лугов, сельскохозяйственных земель и земель, занятых населенными пунктами и объектами инфраструктуры. Также на карте была отображена дорожная сеть - из асфальтированных и грунтовых дорог, улиц первого и второго порядка, а также железнодорожных путей - в силу своей первоочередности в освоении территорий человеком. Принадлежность какого-либо участка земли к той или иной категории определялось посредством дешифрирования космических снимков.

На основе картографирования структуры использования земель было выявлено, что в сентябре 2017 г. 59,7 \% занято лесами (59,14 $\%$ в Партизанском районе и 61,34 \% в Партизанском ГО). Леса распространены практически повсеместно, но районом их наибольшего сосредоточения является восточная часть участка исследования (что, вероятно, связано с малой освоенностью земель в хозяйственном плане и, следовательно, ее относительно малым охватом транспортной сетью). Преобладают лесные угодья в северо-западной части Партизанского муниципального района, и на крайнем севере Партизанского городского округа, что связано с вышеназванными причинами. Ближе к землям населенных пунктов, сельскохозяйственным угодьям и лу- 
гам лесные угодья начинают рассекаться и впоследствии вымещаться редколесьями (что особенно характерно для центральной части Партизанского муниципального района). В результате вырубок лесные угодья при полном сведении древостоя замещаются сукцессионными группировками, которые могут быть представлены редколесьями и лугами; а при частичном сведении - редколесьями.

В Партизанском районе лесные угодья имеют наибольшее cocpeдоточение на крайнем юго-востоке и юго-западе района, а также на севере и востоке района, которые отличаются малой хозяйственной освоенностью и малым охватом транспортно-дорожными сетями. В Партизанском районе лесные угодья наибольшее сосредоточение находят в западной и южной части региона, которые также отличаются малой хозяйственной освоенностью и малым охватом транспортными сетями. Таким образом, в Партизанском районе доля лесных угодий в площади в целом меньше. Это связано с тем, что Партизанский район более равномерно освоен в хозяйственном в плане, чем Партизанский ГО (где территории высокой хозяйственной освоенности в основном приурочены к г. Партизанск). Стоит отметить, что доля лесных угодий, возможно, будет уменьшаться, в результате увеличения лесозаготовительной деятельности в регионах. Так, в структуре ВРП Партизанского района лесозаготовка занимала 3,9 \% в 2017 г. и 4,1 \% за 9 мес. 2018 г. Данные по объемам лесозаготовки в Партизанском ГО отсутствуют [1-2].

$22,9 \%$ территории исследуемых районов занято редколесьями (22,21 \% в Партизанском районе и 23,24\% в Партизанском ГО) (рис., табл.). Наибольшее распространение редколесья получили на юге Партизанского муниципального района, особенно на границе с Находкинским городским округом. Можно сказать, что этот участок один их наиболее выгодных в хозяйственном освоении на исследуемой территории в силу того, что он в транспортном отношении связан с одним из крупнейших портов Дальнего Востока. Редколесья также примыкают к долине р. Партизанская и ее притокам, так как она отличается относительно высокой хозяйственной освоенностью и там активно осуществляется сельскохозяйственная деятельность, что тоже требует разрежения древостоя. В Партизанском ГО редколесья встречаются практически повсеместно. В связи с интенсивным сведением лесов, весьма крупная область редколесий имеется и на севере Партизанского района, который в принципе отличается преобладанием 
лесных угодий. В данном случае редколесья являются сукцессионной группировкой на месте сведенных лесов. В целом же, можно сказать, что редколесья примыкают к транспортным узлам и речным долинам и в большинстве случаев образуются за счет рубки лесов. В Партизанском районе редколесья, как говорилось ранее, сосредоточены в южной части района, примыкающей к Находкинскому городскому округу, а также в долине р. Партизанская и на севере Партизанского, где интенсивно производятся рубки леса. В Партизанском ГО редколесья распространены практически повсеместно, наибольшее их сосредоточение наблюдается в долинах рек и вокруг территорий населенных пунктов и сельскохозяйственных угодий.

$7,7 \%$ исследуемой территории заняты горно-тундровой и подгольцовой растительностью $(8,71 \%$ в Партизанском районе и $4,38 \%$ в Партизанском ГО). Эти земли малопригодны для использования в хозяйстве. В целом, они приурочены к Ливадийскому хребту на юго-западе исследуемой территории, горам Пржевальского на севере и северо-западе, а также к Партизанскому хребту на востоке. Партизанский район своей юго-западной оконечностью захватывает восточный склон Ливадийского хребта; северной оконечностью горы Пржевальского, а на восточной границе района расположены Партизанский и Алексеевский хр. Партизанский ГО на юге захватывает отроги Ливадийского хребта, а на севере - часть гор Пржевальского.

5,78 \% исследуемой территории занята лугами (доля лугов в регионах равна). Этот тип земель приурочен к транспортным узлам, населенным пунктам, сельскохозяйственным угодьям и пр., т. е. к районам, отличающимся относительно высокой освоенностью в хозяйственном плане. Стоит также отметить, что луга могут образовываться не только в результате рубок леса, но и в результате длительного неиспользования сельскохозяйственных угодий. Вне районов активной сельскохозяйственной деятельности (долины р. Партизанская и ее притоков) распространение лугов имеет очаговый характер. Наибольшая концентрация таких очагов наблюдается в северной части Партизанского района и, как уже упоминалось ранее, является результатом образования сукцессионных группировок на месте вырубок лесов. Итак, в Партизанском районе луга приурочены к местам рубки леса на севере района и имеют очаговое распространение. В долине p. Партизанская они окаймляют районы высокого хозяйственного ос- 


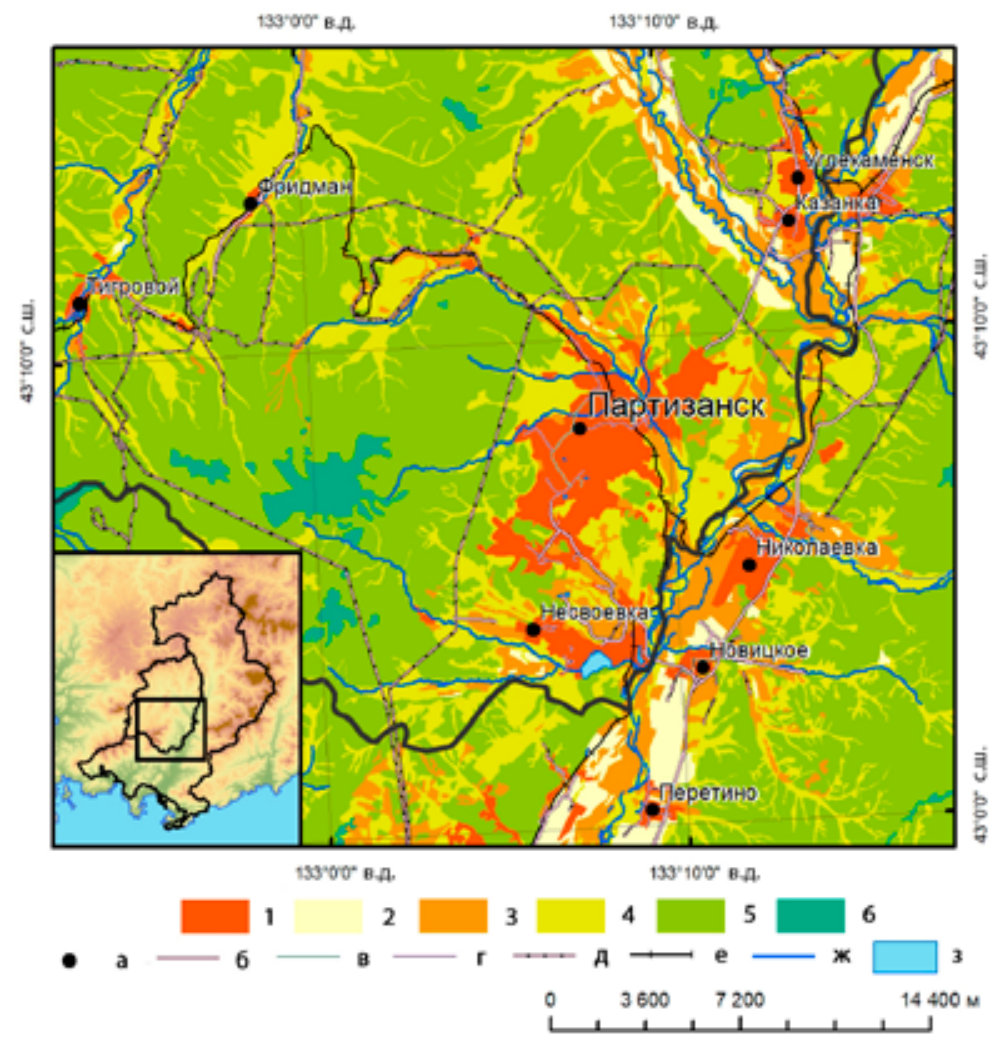

Рис. Фрагмент карты использования земель Партизанского района и Партизанского ГО.

Типы земель: 1 - населенные пункты; 2 - сельскохозяйственные земли; 3 луга; 4 - редколесья; 5 - леса; 6 - горно-тундровая и подгольцовая растительность. Транспортная сеть и водные объекты: а - населенные пункты; б - асфальтированные дороги; в -улицы первого порядка; г- улицы второго порядка; д - железные дороги; ж - реки; з - озера.

воения - то есть, сельскохозяйственные угодья и земли населенных пунктов. Доля лугов в долине р. Партизанская растет при движении с севера на юг района, достигая своей наибольшей концентрации в районе между г. Новицкое, п. Николаевка и с. Перетино. Также много лугов в районе между с. Волчанец и с. Васильевка. Высоким хозяйственным освоением отличается и крайний юг Партизанского района, примыкающий к Находкинскому городскому округу. В Партизанском городском округе луга приурочены практически исключительно к до- 
линам р. Партизанская и ее притоков. Земли лугов как бы лучеобразно отходят от г. Партизанск по долинам рек, также окаймляя земли населенных пунктов и сельскохозяйственные угодья.

Т а бл и ца

Структура использования земель

в Партизанском муниципальном районе и Партизанском ГО

\begin{tabular}{|c|c|c|c|c|c|c|}
\hline \multirow[t]{2}{*}{ Тип земель } & \multicolumn{2}{|c|}{$\begin{array}{c}\text { Партизанский } \\
\text { муниципальный } \\
\text { район }\end{array}$} & \multicolumn{2}{|c|}{ Партизанский ГО } & \multicolumn{2}{|c|}{$\begin{array}{c}\text { Партизанский } \\
\text { муниципальный } \\
\text { район и } \\
\text { Партизанский ГО }\end{array}$} \\
\hline & $\begin{array}{c}\text { Площадь, } \\
\text { км }^{2} \\
\end{array}$ & $\begin{array}{c}\text { Доля, } \\
\%\end{array}$ & $\begin{array}{c}\text { Площадь, } \\
\text { км }^{2} \\
\end{array}$ & $\begin{array}{c}\text { Доля, } \\
\%\end{array}$ & $\begin{array}{c}\text { Площадь, } \\
\text { км }^{2} \\
\end{array}$ & $\begin{array}{c}\text { Доля, } \\
\%\end{array}$ \\
\hline Населенные пункты & 70,03 & 1,68 & 51,71 & 3,96 & 121,56 & 2,22 \\
\hline $\begin{array}{l}\text { Сельскохозяйственные } \\
\text { земли }\end{array}$ & 107,30 & 2,57 & 16,82 & 1,29 & 124,12 & 2,26 \\
\hline Луга & 241,62 & 5,78 & 75,48 & 5,78 & 317,11 & 5,78 \\
\hline Редколесья & 924,13 & 22,12 & 303,41 & 23,24 & 1227,55 & 22,39 \\
\hline Лeca & 2470,29 & 59,14 & 800,72 & 61,34 & 3271,05 & 59,66 \\
\hline $\begin{array}{l}\text { Горно-тундровая } \\
\text { и подгольцовая } \\
\text { растительность }\end{array}$ & 363,86 & 8,71 & 57,20 & 4,38 & 421,20 & 7,68 \\
\hline Всего & 4177,24 & 100 & 1305,35 & 100 & 5482,59 & 100 \\
\hline
\end{tabular}

Сельскохозяйственными землями занято 2,3 \% территории $(2,57$ \% в Партизанском районе и 1,29 \% в Партизанском ГО). Большинство сельскохозяйственных угодий приурочено к долине р. Партизанская и ее притокам, что, вероятно, можно обосновать повышенным плодородием почв в данном месте, а также облегчает использование водных ресурсов для нужд сельского хозяйства. Как правило, они находятся в незначительном удалении от населенных пунктов и/или транспортных узлов. Вне долины р. Партизанская и ее притоков сельскохозяйственные угодья не встречаются. И в Партизанском районе, и в Партизанском городском округе сельскохозяйственные земли приурочены исключительно к долине р. Партизанская. Партизанский район захватывает большую часть долины р. Партизанская, следовательно, доля сельскохозяйственных угодий у него будет больше, чем у Партизанского ГО. Доля сельского хозяйства составила 16,7 \% в ВРП Партизанского района в 2017 г. и 15,4 \% - за 9 мес. 2018 г. В Партизанском ГО его доля составляла 6,5 \% в 2017 г. и 7,6 \% за 9 мес. 2018 г. [1-3]. Таким образом, площади сельскохозяйственных угодий могут 
либо сохранить свои позиции, либо расшириться за счет лугов, например, в Партизанском ГО.

$2,2 \%$ территории районов занято землями населенных пунктов и объектами инфраструктуры (1,68 \% в Партизанском районе и 3,96 \% в Партизанском ГО), которые в основном приурочены к долине р. Партизанская, располагаясь в непосредственной близости к сельскохозяйственным угодьям, лугам и редколесья, что соответствует основной специализации района - сельскохозяйственной и лесозаготовительной. В Партизанском районе практические отсутствуют крупные населенные пункты - в основном преобладают села и поселки сельского типа. Хотя в Партизанском городском округе ситуация в целом такая же, в его состав входит крупнейший населенный пункт изучаемой территории - г. Партизанск, наличие которого и объясняет превосходство Партизанского городского округа в этой категории. Населенные пункты, как правило, приурочены либо к узлам транспортной сети (например, железнодорожным станциям), либо к бассейну р. Партизанская (т.е. к районам активной сельскохозяйственной деятельности). В целом, кроме г. Партизанск, с. Владимиро-Александровское и с. Сергеевка, населенные пункты Партизанского муниципального района и Партизанского ГО имеют незначительную площадь (что особенно характерно для Партизанского ГО). Стоит отметить, что некоторые населенные пункты Партизанского ГО имеют численность населения до 200 человек и, в основном, выполняют роль транспортного узла (к примеру, ж/д станция Фридман с населением около 40 чел.). Вне долины р. Партизанская населенные пункты практически отсутствуют (за исключением с. Хмыловка, п. Волчанец и д. Васильевка). В ВРП Партизанского района строительный сектор занимал 10,8 \% в 2017 г. и 7,7 \% в 2018 г., а в ВРП Партизанского ГО он составлял $0,3 \%$ в 2017 г. и 0,5 \% в 2018 г. [1-3]. Из статистических данных сложно сделать однозначный вывод о дальнейшей динамике земель населенных пунктов.

В общем, можно сказать, что структуру земель Партизанского района от структуры земель Партизанского городского округа отличает более высокая доля сельскохозяйственных земель, что и было отражено в структуре ВРП административных единиц - 16,7 \% ВРП Партизанского района занимал сельскохозяйственный сектор в 2017 г., а в Партизанском ГО - 6,5\%. Также в Партизанском муниципальном районе, в силу орографических особенностей, выше доля земель 
с горно-тундровой и подгольцовой растительностью. В Партизанском ГО значительно выше доля земель населенных пунктов (за счет того, что в его состав входит г. Партизанск) и лесных угодий (что связано с менее интенсивной, чем в Партизанском районе, рубкой леса) $[1,3]$.

Из приведенных выше данных становится понятно, что исследуемые районы имеют преимущественно сельскохозяйственную и лесозаготовительную специализацию. Вследствие этого можно ожидать уменьшение площади лесов и лугов и увеличение площади сельскохозяйственных земель и редколесий. Однако, интенсивная вырубка лесов может привести к серьезным экологическим последствиям. В связи со сведением лесов теряется способность территории поглощать углекислый газ, может усилиться парниковый эффект, который будет оказывать иссушающее и отепляющее влияние на климат (что неблагоприятно скажется на муссонном климате территории, который имеет крайне неравномерное распространение осадков). Сведение лесов и прочей растительности с территории может привести к активизации склоновых процессов, эрозии почв посредством поверхностного смыва, ветровой дефляции и пр.

Также по результатам визуальной дешифровки удалось установить, что сельскохозяйственный потенциал территории используется не полностью. Наблюдалось, что некоторые сельскохозяйственные земли, в результате их длительного неиспользования, испытали переход в другую категорию классификации - луга. В основном земли, отличающиеся высокой и средней антропогенной модифицированностью (земли населенных пунктов, сельскохозяйственные земли, луга, редколесья), приурочены к долине р. Партизанская и ее притоков. Районы вне долины р. Партизанская, наоборот, отличаются малой освоенностью и малым охватом дорожной сетью.

Основное различие между структурами землепользования Партизанского муниципального района и Партизанского городского заключается в том, что в Партизанском муниципальном районе более высокая доля сельскохозяйственных земель и земель с горно-тундровой и подгольцовой растительность (в силу орографических особенностей). А в Партизанском городском округе выше доля земель населенных пунктов и лесных угодий, в силу менее интенсивного хозяйственного освоения территории.

Научный руководитель: профессор кафедры географии и устойчивого развития геосистем ШЕН ДВФУ, к.г.н. Зонов Ю.Б. 


\section{Литература}

1. Итоги социально-экономического развития за 2017 год // Администрация Партизанского городского округа [Электронный ресурс]. - Режим доступа: http:// www.partizansk.org/upravlenie_ekonomiki_i_sobstvennosti_informaciya_ob_ekonomicheskom_razvitii_partizanskogo_5 (дата обращения: 09.04.2019).

2. Итоги социально-экономического развития ПГО за 9 месяцев 2018 года // Администрация Партизанского городского округа [Электронный ресурс]. - Режим доступа: http://www.partizansk.org/upravlenie_ekonomiki_i_sobstvennosti_informaciya ob_ekonomicheskom_razvitii_partizanskogo_9 (дата обращения: 09.04.2019).

3. Статистическая информация о деятельности администрации Партизанского муниципального района. [Электронный ресурс]. - Режим доступа: http://rayon. partizansky.ru/?id=20120313091141\&COMSD=20120313091141 (дата обращения: 09.04.2019).

\section{References}

1. Itogi social'no-e'konomicheskogo razvitiya PGO za 2017 god [Administration of Partizansky Urban Okrug]. Available at: http://www.partizansk.org/upravlenie ekonomiki_i_sobstvennosti_informaciya_ob_ekonomicheskom_razvitii_partizanskogo_5. (accessed 09.04.2019).

2. Itogi socialno-ekonomicheskogo razvitiya PGO za 9 mesyacev 2018 goda [Results of socio-economic development of Partizansky Urban Okrug in 9 months of 2018]. Available at: http://www.partizansk.org/upravlenie_ekonomiki_i_sobstvennosti_informaciya_ob_ ekonomicheskom_razvitii_partizanskogo_9. (accessed 09.04.2019).

3. Statisticheskaya informaciya o deyatelnosti administracii Partizanskogo municipalnogo rajona [Statistical information on Administration of Partizansky District's activity]. Available at: http://rayon.partizansky.ru/?id=20120313091141\&COM $\mathrm{SD}=20120313091141$ (accessed 09.04.2019). 